\title{
THE LATE PLEISTOCENE (RANCHOLABREAN) VIKO VIJIN LOCAL FAUNA FROM LA MIXTECA ALTA, NORTHWESTERN OAXACA, SOUTHERN MEXICO
}

\author{
EDUARDO JIMÉNEZ-HIDALGO, ROSALÍA GUERRERO-ARENAS \\ Laboratorio de Paleobiología, Instituto de Recursos, Campus Puerto Escondido, Universidad del Mar, Carretera Puerto \\ Escondido, Oaxaca, CP 71980, Mexico. eduardojihi@gmail.com, rosaliaga@zicatela.umar.mx \\ BRUCE J. MACFADDEN \\ Florida Museum of Natural History, University of Florida, Gainesville, FL 32611-7800, USA. bmacfadd@flmnh.ufl.edu
}

\section{LUCÍA CABRERA-PÉREZ}

Licenciatura en Biología, Campus Puerto Escondido, Universidad del Mar, Carretera Puerto Escondido, Oaxaca, CP 71980, Mexico.cabreraluc@hotmail.com

\begin{abstract}
Paleontological work carried out in the Late Pleistocene floodplain and bar fluvial deposits of northwestern Oaxaca, southern Mexico, resulted in collecting cranial and poscranial material of mammals identified as Glyptotherium, Hemiauchenia, Camelops, Odocoileus, two Equus species, Cuvieronius, Mammuthus and Bison. The presence of Bison in all the localities indicates a Rancholabrean North American Land Mammal age for the faunal assemblage. Also, many mollusk specimens were collected and belong to five families of terrestrial gastropods, three families of freshwater gastropods, and one family of freshwater bivalves. Additionally, several fragments of Rodentia indet., sigmodontine rodents, and scincomorph lizards were also recovered through the screen-washing of sediments. This faunal association was designed herein as the Viko vijin (cold epoch or period in Mixteca language) Local Fauna (L. F.) and shares nine mammalian taxa with the Rancholabrean local faunas of Terapa (Sonora, NW Mexico), Chapala (Jalisco), El Cedazo (Aguascalientes) and Tequixquiac (Mexico), central Mexico. Likewise, five of the eight mollusk families identified are also present in the Late Pleistocene Rancho La Amapola, San Luis Potosi, Central Mexico. The presence of the llama Hemiauchenia in Oaxaca represents the southern-most record of this genus during the Late Pleistocene in North America, while Late Pleistocene scincomorph lizards are recorded for first time in Oaxaca. Similarly, the records of the mollusk families Bulimulidae, Polygyridae and Urocoptidae in the Mixteca Alta Oaxaqueña are the first for Mexico and allow extend their geographic ranges from southern USA to southern Mexico during the Late Pleistocene.
\end{abstract}

Key words: Pleistocene, Rancholabrean, Mammalia, Mollusca, Oaxaca, Mixteca.

RESUMO - O estudo dos depósitos fluviais de planície de inundação e de barras fluviais do Pleistoceno tardio do noroeste de Oaxaca permitiu recuperar diversos exemplares de mamíferos identificados como Glyptotherium, Hemiauchenia, Camelops, Odocoileus, duas espécies de Equus, Cuvieronius, Mammuthus e Bison. A presença de Bison em todas as localidades indica uma idade norte-americana de mamíferos do Rancholabreano para a associação faunística. Também foram recuperados diversos exemplares atribuídos a cinco famílias de gastrópodes terrestres e três famílias de gastrópodes dulceaquícolas, assim como a uma família de bivalves dulceaquícolas. Adicionalmente, mediante o peneiramento dos sedimentos foram recuperados alguns elementos de Rodentia indet., roedores da subfamília Sigmodontinae e de lacertilios scincomorfos. Designou-se Fauna Local Viko vijin (época ou período de frio na língua Mixteca) a esta associação faunística, que compartilha nove táxons de mamíferos com as faunas rancholabreanas de Terapa (Sonora, NE México), Chapala (Jalisco), El Cedazo (Aguascalientes) e Tequixquiac (México), México central. Também, são compartilhadas cinco famílias de invertebrados com Rancho La Brisca, Pleistoceno tardio de San Luis Potosí (México central). O registro da lhama Hemiauchenia em Oaxaca é o mais austral para América do Norte durante o Pleistoceno tardio e o de lacertilios scincomorfos, o primeiro no Pleistoceno de Oaxaca. Os registros das famílias Bulimulidae, Polygyridae e Urocoptidae são os primeiros para o México e permitem estender a distribuição geográfica destes táxons de moluscos desde o sul dos Estados Unidos até o sul do México, durante o Pleistoceno tardio.

Palavras-chave: Rancholabreano, Pleistoceno, Mammalia, Mollusca, Oaxaca, Mixteca.

\section{INTRODUCTION}

The Pleistocene is the most recent geologic epoch before Holocene, beginning about 2.58 My and ending between 10,000 or 9,500 years BP (Walker \& Geissman, 2009). It is characterized by a great climatic instability that had severe impact on the taxonomic richness, geographic distribution, and structure of the North American animal communities (Arroyo-Cabrales et al., 2002; Montellano-Ballesteros \& Jiménez-Hidalgo, 2006). 
The Pleistocene was also the last geologic epoch when a great diversity of large mammals inhabited North America, such as mammoths, glyptodonts, horses, camels, ground sloths, dire wolves and saber-tooth cats, among others. Its ending is marked by a great extinction of the megafauna in various continents. It is estimated that around $72 \%$ of large mammal genera became extinct in North America and at present there is not agreement about what caused this massive decrease in mammalian biodiversity (Koch \& Barnosky, 2006; Prothero, 2006; Gill et al., 2009).

Mexican Pleistocene sediments are widely distributed and it is common to find fossil remains all over the country, but unfortunately, a large part of faunal discoveries are isolated, without stratigraphic control. In many instances, there is neither locality information nor are the taxonomic identifications accurate (Arroyo-Cabrales et al., 2002). The better-studied Pleistocene Mexican faunas include the Irvingtonian El Golfo de Santa Clara, in Sonora, as well as the Rancholabrean faunas: Rancho La Brisca and Terapa (Lindsay, 1984; Van Devender et al., 1985; Mead et al., 2006), Chapala in Jalisco (Lucas, 2008 and references therein), San Josecito Cave in Nuevo Leon (Arroyo-Cabrales \& Johnson, 1995, 2003, and references therein), Tequixquiac in the State of Mexico (Hibbard, 1955), Santa Cruz Nuevo in Puebla (Tovar et al., 2007); the Irvingtonian-Rancholabrean El Cedazo fauna, from Aguascalientes (Mooser \& Dalquest, 1975; MontellanoBallesteros, 1992); and the Late Pleistocene and Holocene Loltún Cave in Yucatán (Arroyo-Cabrales \& Álvarez, 2003; Morales-Mejía et al., 2009). Except for the last one, the faunas are located in northern and central Mexico, i.e., within or north to the Transmexican Volcanic Belt; thus, there is much more information about the Neartic Pleistocene faunas compared with those from the Neotropical southeastern (or southern) Mexico (Ferrusquía-Villafranca et al., 2007; Jiménez-Hidalgo et al., 2007).

Consequently, at present the picture of the Mexican Pleistocene fauna is biased because the knowledge of the Neotropical community is incomplete. It is unknown if the Late Pleistocene extinction event was isochronous with that from the temperate North America, or as in the Pliocene, some lineages persisted longer in subtropical and tropical North America than in the northern areas (Jiménez-Hidalgo \& Carranza-Castañeda, 2005; Montellano-Ballesteros \& JiménezHidalgo, 2006; Jiménez-Hidalgo \& Carranza-Castañeda, 2009). Also, biogeographic patterns of Pleistocene North American mammals cannot be completely reconstructed at present because there is not enough information about the geographic distribution of many species (MontellanoBallesteros \& Jiménez-Hidalgo, 2006; Jiménez-Hidalgo et al., 2007; Arroyo-Cabrales et al., 2008).

In the State of Oaxaca (southern Mexico) the twentyknown Pleistocene mammal localities represent the $2.58 \%$ of all the Mexican Pleistocenic localities (Arroyo-Cabrales et al., 2002). Published descriptions with taxonomic identification of the fossil material and stratigraphic descriptions of localities do not exist or sometimes they are in grey literature (e.g. Doutt \& Craig, 1962; Ochoterena \&
Silva-Bárcenas, 1970; Silva-Bárcenas, 1993; Quevedo-Robles \& Quevedo de Henell, 2001). This is also the case for the Mixteca Alta (a culturally important region of northwestern Oaxaca in which the prehispanic Mixteca culture developed), where there are just three brief mentions of Pleistocene mammals (Doutt \& Craig, 1962; Ferrusquía-Villafranca, 1970; Quevedo-Robles \& Quevedo de Henell, 2001).

With the aim of increasing the information of the Neotropical Mexican Pleistocene faunas, and particularly those of the Pleistocene of Oaxaca, a paleontological project was carried on in the area of la Mixteca Alta, northwestern Oaxaca. The assemblage of invertebrates, reptiles and mammals recovered from the Late Pleistocene sediments of the study area (Figure 1), is named Viko vijin Local Fauna (L. F.), which in Mixtecan language means "cold epoch, period or time." The purpose of this paper is to describe these new fossil localities, to make some remarks about the taphonomy and identified vertebrates and mollusk taxa and to settle some inferences about the probable habitat of the study area during the Late Pleistocene.

The taxa collected include medium to very large-sized mammals as well as terrestrial and freshwater gastropods and bivalves (Figures 3, 4). Additionally, diverse mollusks, rodent molars and lizard remains represent the microfossils.

The fossil material is now under detailed study and it will be formally described in subsequent papers. Here, it is convenient to make some comments about the characters observed in the taxa identified, and about the significance of their records in the Late Pleistocene of the Mixteca Alta oaxaqueña.

The specimens are housed at the Colección Científica del Laboratorio de Paleobiología, Instituto de Recursos, campus Puerto Escondido, Universidad del Mar, under the prefix UMLP for invertebrates and UMPE for vertebrates. Upper and lower teeth are represented by upper and lower case: $\mathrm{DP} / \mathrm{dp}$ (deciduous premolar), $\mathrm{P} / \mathrm{p}$ (premolar), $\mathrm{M} / \mathrm{m}$ (molar). All measurements are expressed in millimeters ( $\mathrm{mm})$.

\section{GEOLOGIC SETTING AND TAPHONOMY}

The study area is within the Sierra Madre del Sur physiographic province and the Tierras Altas de Oaxaca subprovince, between $17^{\circ} 35^{\prime}-17^{\circ} 55^{\prime} \mathrm{N}$ and $97^{\circ} 20^{\prime}-97^{\circ} 40^{\prime} \mathrm{W}$ (Figure 1). The area shows a complex relief with an altitude between 1800-2400 $\mathrm{m}$ and diverse intermontane basins, which are filled with continental deposits of Tertiary and Quaternary age (Ortíz Pérez et al., 2004).

\section{General geology of the study area}

The oldest rock outcrops in the area are the Cretaceous limestones and dolomites of the Teposcolula Formation, and marl of the Yucumana Formation. These marine rocks are discordantly overlain by the Paleocene?-Eocene Tamazulapan Formation, composed of a carbonaceous conglomerate with a sandy matrix, which also discordantly underlies the Yanhuitlan Formation, the latter consisting of red to cream colored clay, siltstone and some fine-grained sandstone beds of Middle Eocene age (Ferrusquía-Villafranca, 1970; Gonzáles- 
Ramos et al., 2000; Santamaría-Díaz et al., 2008). Oligocene rocks include the informal volcaniclastic Teotongo unit, represented by greenish gray tuffaceous sandstone and lithic tuff (Santamaría-Díaz et al., 2008) and the Llano de Lobos Tuff, constituted by pink tuff, tuffaceous siltstone, ignimbrite, conglomerate and sandstone (Ferrusquía-Villafranca, 1970); both units discordantly overlie the Yanhuitlan Formation. Finally, Quaternary deposits cap the stratigraphic sequence filling the lower part of valleys, rivers and ravines of the study area, as described in more detail below. At different sites there are diverse andesitic intrusive bodies of Permian to Miocene age (Santamaría-Díaz et al., 2008).

\section{Stratigraphy of fossil localities}

The Pleistocene fossils have been recovered from six localities that are within the ravines of the municipalities of Concepción Buenavista, San Antonio Acutla, Teotongo and Villa Tejupam de la Unión (Figure 1). The fossil localities are sequentially numbered as: Oax-2 El Pedernal, Oax-3 La Pedrera, Oax-4 Río Salado, Oax-5 Llano de Hueso, Oax-6 Cañada del Misterio and Oax-7 Río Tejupam. The stratigraphic description of each locality is given below.

In the northeastern part of the study area, southwest of the town of Concepción Buenavista, in the locality Oax-2 El Pedernal, the stratigraphic sequence begins with a light greenish gray (10Y 8/1), medium bedded vitric tuff that is discordantly covered by a light greenish gray colored (10Y 7/1) massive bed, constituted by well-indurated, poorly sorted, fine- and medium-grained sand with subangular to subrounded clasts; it bears lenses of silt and gravel at several levels (Figure 2). A characteristic feature of this bed is the presence of 2.0-10.0 cm diameter nodular caliche or calcrete, especially in its bottom half. The Pleistocene fossil specimens where recovered from the basal part $(50-100 \mathrm{~cm})$ of this massive sandy bed. In some places it shows cross bedding, whereas in others it appears pseudo-stratified. The caliche nodules are in the same fossiliferous level bed and sometimes are in direct association with the fossil specimens. The fossil bearing bed is discordantly overlain by four thick beds of fine- and medium grained light brown (7.5 YR 6/3) sand, with some lenses of gravel in the first two bottom beds. In the top of the sequence there is a layer of soil of about $35 \mathrm{~cm}$ (Figure 2).

To the northeast of the Concepción Buenavista, in locality Oax-3 La Pedrera, the base of the stratigraphic sequence is represented by fine-grained, pale yellow $(2.5 \mathrm{Y} 8 / 2)$, crossstratified tuffaceous sand with laminar stratification, which is discordantly overlain by a breccia with dark brown (10YR $3 / 3$ ) basalt clasts and sandy matrix. The breccia is discordantly overlain by a thick bed of pale yellow $(2.5 \mathrm{Y} 8 / 3)$ silty clay with few lenses of gravel and moderately sorted fine-grained sand (Figure 2). This bed becomes more compact towards its bottom, so, apparently it is composed by three layers, of which the middle bears the Pleistocene fossils. In this bed there are several caliche nodules with a diameter of $1.0 \mathrm{~cm}$ to $8.0 \mathrm{~cm}$, which also are associated with the fossils. A gravel layer with clasts from 2 to $10 \mathrm{~cm}$ in diameter and sandy matrix caps the silty clay bed. Above the gravel there is a soil bed of around $30 \mathrm{~cm}$ thick.

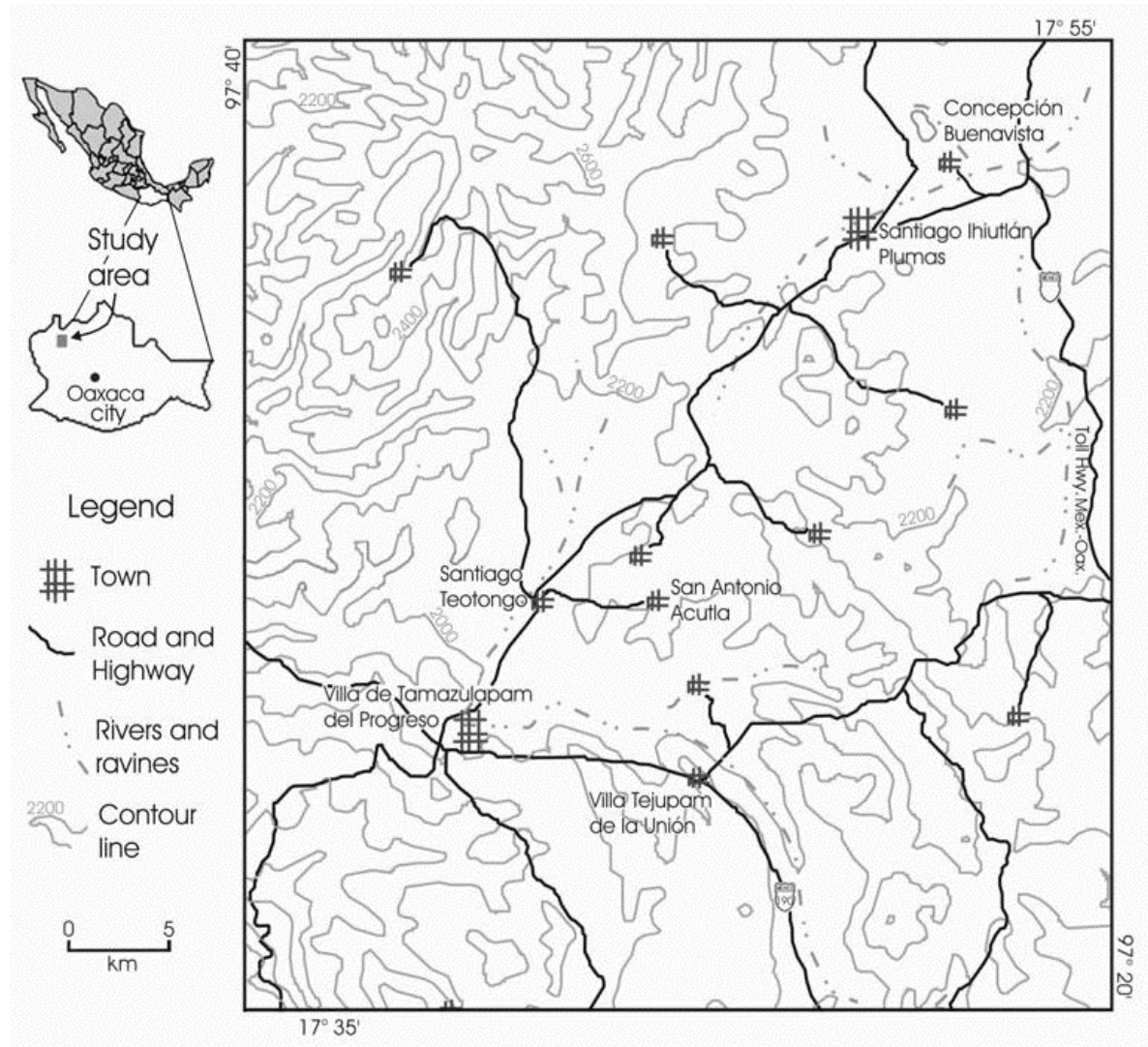

Figure 1. Topographic map of the study area in northwestern Oaxaca, southern Mexico. 
In the surroundings of Santiago Teotongo and San Antonio Acutla (Figure 1), in localities Oax-4 Río Salado, Oax-5 Llano de Hueso and Oax-6 Cañada del Misterio, the stratigraphic sequence starts with the Yanhuitlan Formation that in some places contain gypsum filling fractures; it is discordantly covered by a thick bed of light olive gray ( $5 \mathrm{Y} 6 /$ 2 ), well-indurated, fine-grained silty sand with lenses of poorly sorted, fine- and medium-grained sand as well as gravel (Figure 2); within the gray fine-grained silty sand there are small rhizolithes (1-5 $\mathrm{mm}$ in length). The Pleistocene fossils have been collected from this bed and there also are several calcrete or caliche nodules within it that sometimes are associated with fossils. Three beds of reddish brown (5 YR $5 / 4$ ), fine-grained silty sand with some gravel lenses discordantly cover the fossiliferous bed. Capping the sequence there is a $\sim 35 \mathrm{~cm}$ thick soil layer.

Near Villa Tejupam de la Unión (Figure 1), in locality Oax7 Río Tejupam, the stratigraphic sequence is similar to the description above, it only differs in that the fossil bearing bed is a light olive brown (2.5Y 5/3), fine-grained silty sand with lenses of clay and gravel (Figure 2). As in the other Pleistocene sediments, Oax-7 bears several calcrete nodules ranging from $1 \mathrm{~cm}$ to $8 \mathrm{~cm}$ in diameter.

The above-described sediments are common in fluvial depositional environments (Boggs, 2001). The fossiliferous sediments of locality Oax-2 El Pedernal apparently were deposited as lateral bar sequences, which are characterized by the presence of medium and fine-grained cross-bedded sand; the absence of very coarse-grained sediments (cobbles and boulders) at the base of the sequence suggest that the deposit is not a longitudinal bar (Reineck \& Singh, 1975; Miall, 1982; Nichols, 1999). In locality Oax-3 La Pedrera, the fine-grained bearing sediment is indicative of a floodplain deposit, which is characterized by the predominance of silt and clay (Boggs, 2001; Nichols, 1999).

The fine-grained sediments of the remaining fossil localities (Oax-4 to Oax-7), suggest that deposition occurred in natural leeves or the upward section of bars, since silt and fine-grained sand dominate such deposits (Miall, 1982; Reineck \& Singh, 1975). The lenses of gravel, sand and clay that are within the fossil bearing sediments in all the localities seem to represent scour-and-fill structures (Reineck \& Singh, 1975).

\section{Taphonomic considerations}

Diverse fossil and sediment characteristics were considered to evaluate the potential taphonomic bias of the faunal assemblage. The mammalian fossil material includes isolated upper and lower molars, isolated poscranial elements (humerus, scapula, radius, tibia, metapodial, vertebrae,

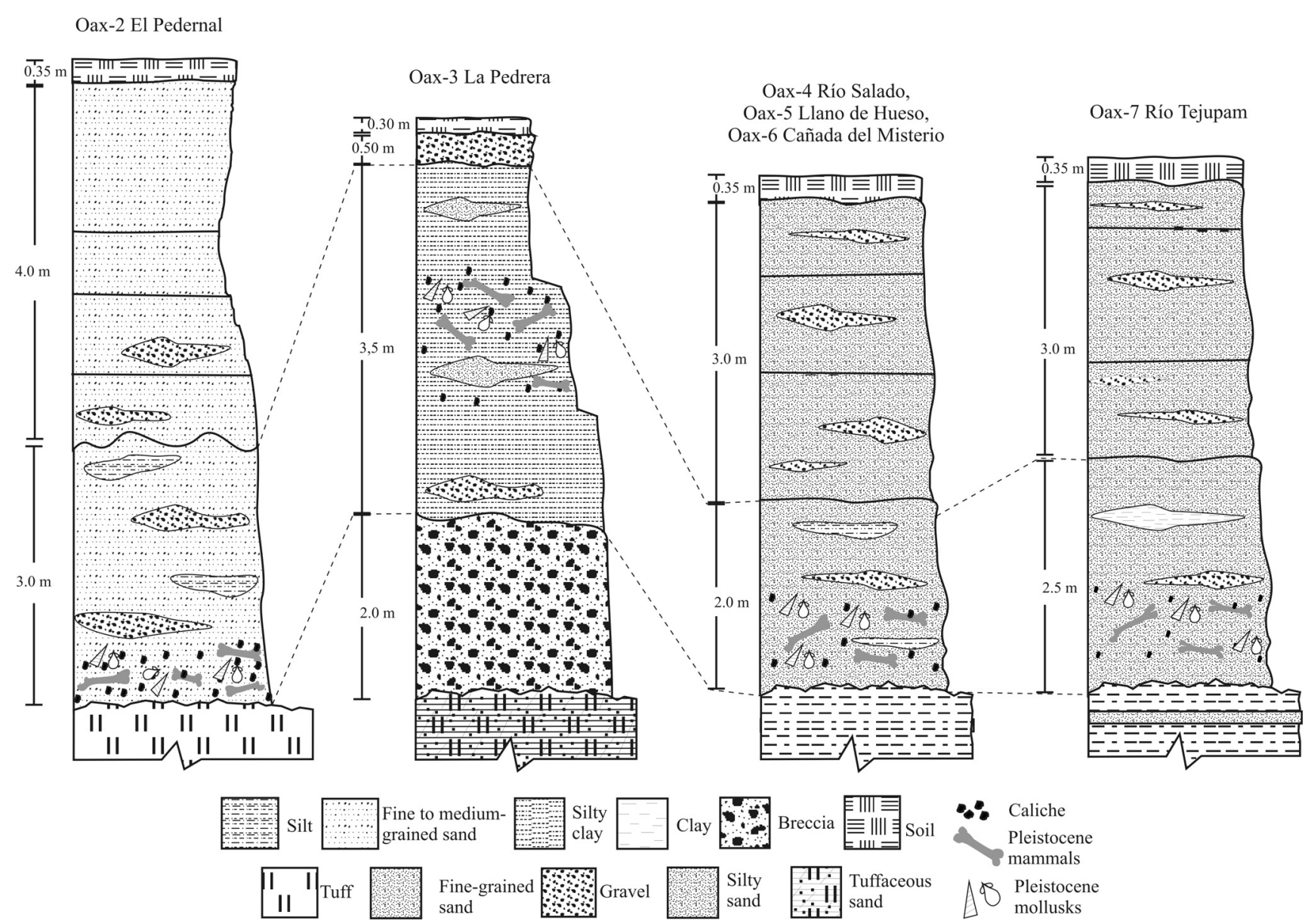

Figure 2. Stratigraphic profiles of the Rancholabrean fossil localities that contain the Viko vijin Local Fauna of the Mixteca Alta oaxaqueña, southern Mexico. 
osteoderms, ribs and sacra), some jaws and skulls with teeth of medium to very large-sized mammals, as well as complete or almost complete mollusk individuals. Thus, the specimens are moderately to well preserved.

In addition to micro-mollusks, sediment screen washing resulted in the recovery of some rodent molars and postcranial fragments, as well as several lizard cranial fragments with teeth and some postcranial fragments from the fine-grained sand-size concentrate. The majority of the mollusk specimens were discovered together in lenses from the same stratigraphic level in which the bones occur; occasionally, bones and mollusks were found close together. Sometimes freshwater gastropods were in direct association with the bones in life position (i.e. with their mouth directed toward the bone surface).

The mollusk specimens do not have signs of dissolution or abrasion and there is not an evident size selection or sorting because individuals of different sizes were found together. Some gastropods lost small parts of the aperture and several bivalve specimens are still articulated.

The above-mentioned observations suggest a short and very limited fluvial transport and a rapid burial of the invertebrates (Kidwell \& Flessa, 1996; Kotzian \& Simões, 2006).

Similarly, the fossil bones were scattered among the localities; they were not concentrated in clusters. A small number of bones show few parallel cracking to fibrous grain of bone on their surface and this cracking is confined to the outermost layer of bone; however, the majority of specimens look "fresh" with no sign of cracking or flaking. So, they can be assigned to weathering stage 0 or stage 1 of Fiorillo (1988) and considered as little weathered. This suggests a rapid burial of specimens after losing their soft tissues, being disarticulated and scattered, given that the bulk of bones were collected as isolated elements.
Various bones are complete while others are broken and incomplete; those broken have sharp and acute edges, which evidence little or no abrasion; also, there is no indication of carnivore modification. Broken bones could result from trampling after burial (Behrensmeyer \& Hook, 1992). Complete specimens have well-defined processes that also are not polished.

The specimens do not have hydraulic equivalence with the fine-grained bearing sediments; they do not show severe water sorting, because bones of each of the three "Voorhies Groups" of dispersal potential in flowing water have been collected, and several fragile specimens such as pelves and skulls were collected complete. Additional indication of limited water sorting of the mammal bones is the 1.27 teeth/vertebrae ratio of the specimens collected. Ratios near 1.0 indicate an unsorted assemblage because vertebrae (easily transported) occur at the same numbers of teeth (difficult to transport) (Cassiliano, 1997). These features suggest very restricted fluvial transport of the mammal bones collected during this study (Cassiliano, 1997; Moore \& Norman, 2009).

Contrary to the bones of medium and large-sized mammals, microvertebrate specimens have hydraulic equivalence with the coarser grains of bearing sediments and some show little polishing, evidence of some fluvial transport. But this might be short because although broken, the majority of specimens are recognizable; also, they are fragile and could not have survived a prolonged transport.

The minimal transport and sorting of vertebrate and invertebrate specimens are strong indicators of the indigenous origin (Raup \& Stanley, 1978) of the Viko vijin L. F., which seems to be produced within the local habitat of the fossilized species.

It is known that time-averaging is common in fluvial depositional environments due to erosional reworking of

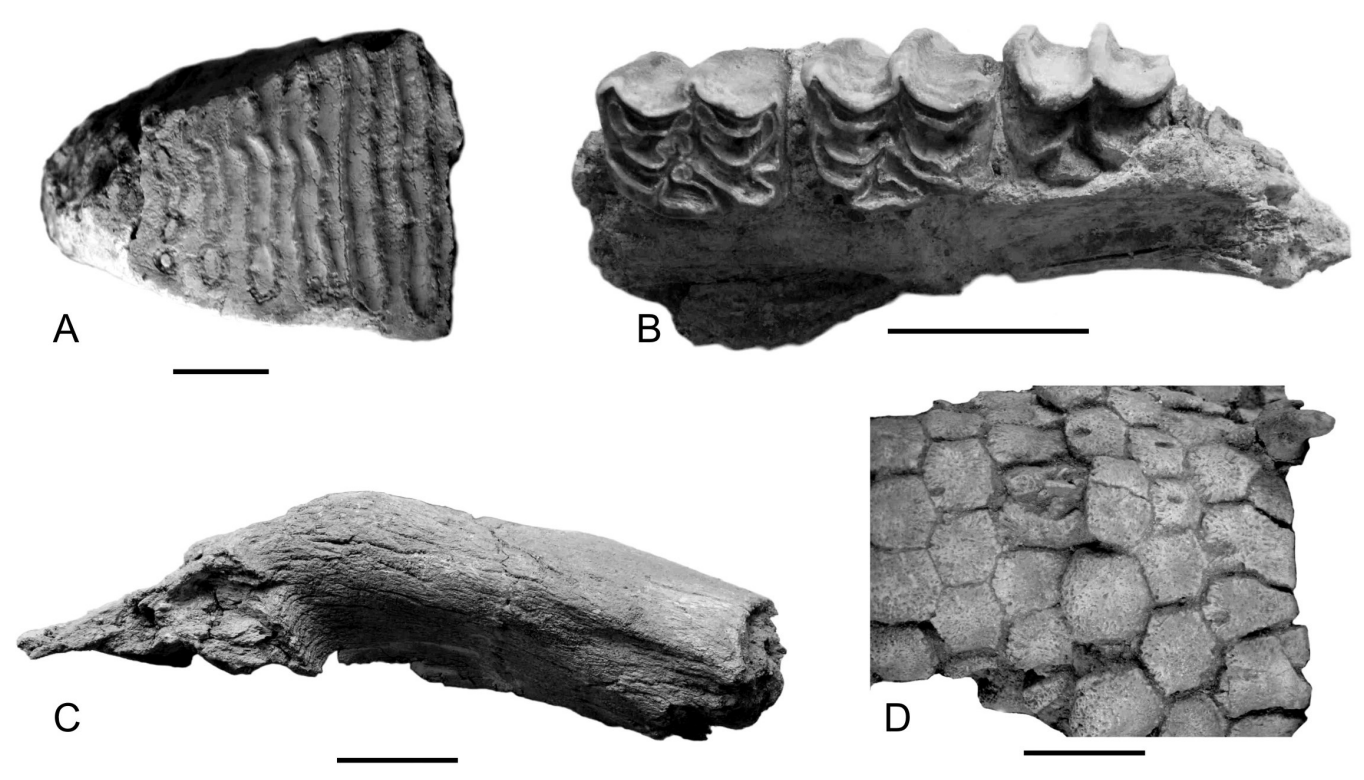

Figure 3. Some mammalian specimens of the Rancholabrean Viko vijin Local Fauna of Oaxaca, southern Mexico. A, Mammuthus lower molar fragment, occlusal view; B, medium-sized Equus teeth series with DP4-M2, occlusal view (rostral side toward left page margin); C, Bison horn-core fragment, caudal view; D, Glyptotherium articulated caudal osteoderms, dorsal view. Scale bars: $\mathrm{A}-\mathrm{C}=3 \mathrm{~cm}$; D = $5 \mathrm{~cm}$. 
overbank deposits, with a time resolution between $10^{2}$ to $10^{4}$ years (Behrensmeyer, 1982; Kidwell \& Flessa, 1996). The almost complete absence of abrasion and polishing of fossil specimens, the occurrence of mostly one weathering stage of mammal bones and the good preservation of the fragile fossil mollusks shells, as well as the presence of just one fossiliferous level in the study area. These evidences likewise suggests that a short-time span is recorded in the Viko vijin L. F, with no signs of substantial temporal mixing or reworking of older fossils into the bearing sediments.

Fluvial fossil assemblages with large amount of timeaveraging contain specimens with diverse weathering stages, the specimens are polished and abraded to several degrees, and the reworked specimens look much different from the rest of the sample (Behrensmeyer, 1982; Kidwell \& Flessa, 1996; Cassiliano, 1997). Additionally, it is common that bones are associated with abundant reworked mud-clasts or carbonate-clasts (Behrensmeyer, 1982) and there is a preponderance of complex and multistoried sheets of sand and moderately developed paleosols in the fossil deposits (Aslan \& Behrensmeyer, 1996), features not observed in the localities described in this study.

Therefore, we consider the Viko vijin L. F. an indigenous (Raup \& Stanley, 1978) and within habitat assemblage carrying an ecological signal (Kidwell \& Flessa, 1996). Without doubt, it represents several communities as defined by ecologist (diverse generations mixed); but it can be considered what some authors refer to as a metacommunity, which therefore allows consideration of the dynamics of natural systems in time and space (Eronen, 2007; Tomašových \& Kidwell, 2010).

\section{SYSTEMATIC PALEONTOLOGY}

\section{Class GASTROPODA \\ Order STYLOMMATOPHORA Schmidt, 1865 \\ Family PUPILLIDAE Pilsbry, 1916}

Referred material. UMLP-Lote 1-Oax 3 with 70 specimens, from locality Oax-3 La Pedrera; UMLP-Lote 2-Oax 3 with 46 specimens, from locality Oax-3 La Pedrera; UMLP-Lote 3Oax 3 with 2 specimens, from locality Oax-3 La Pedrera.

Remarks. The shells of the specimens are small, with a typical pupilliform form, always taller than wide. The aperture is rounded and free.

\section{Family ORTHALICIDAEAlbers, 1850 cf. Orthalicus Beck, 1837}

Referred material. UMLP-Lote 1-Oax 6 with 9 specimens, from locality Oax-6 Cañada del Misterio.

Remarks. These specimens have a big and ovate-conical shell. Their shell surface is smooth. The body whorls are broadly expanded.

\section{Family UROCOPTIDAE Pilsbry, 1898 cf. Anisospira Strebel, 1880}

Referred material. UMLP-Lote 2-Oax 6 with 35 specimens, from locality Oax-6 Cañada del Misterio.

Remarks. The shells of these specimens are decollate and cylindrical, moderately large. The whorls increase in size from the apex to about the middle of shell, thereafter remaining uniform in size. The aperture is free, nearly circular.

\section{Family SUCCINEIDAE Beck, 1837}

Referred material. UMLP-Lote 4-Oax 3 with 45 specimens, from locality Oax-3 La Pedrera; UMLP-Lote 1-Oax 2 with 50 specimens, from locality Oax-2 El Pedernal.

Remarks. These shells are thin and have a pear shape, near ovate. The spire is short. The aperture is large and oval.

$$
\begin{gathered}
\text { Family POLYGYRIDAE Pilsbry, } 1895 \\
\text { Polygyra Say, } 1818
\end{gathered}
$$

Referred material. UMLP-Lote 5-Oax 3 with 34 specimens, from locality Oax-3 La Pedrera; UMLP-Lote 2-Oax 2 with 60 specimens, from locality Oax-2 El Pedernal; UMLP-Lote 3 -

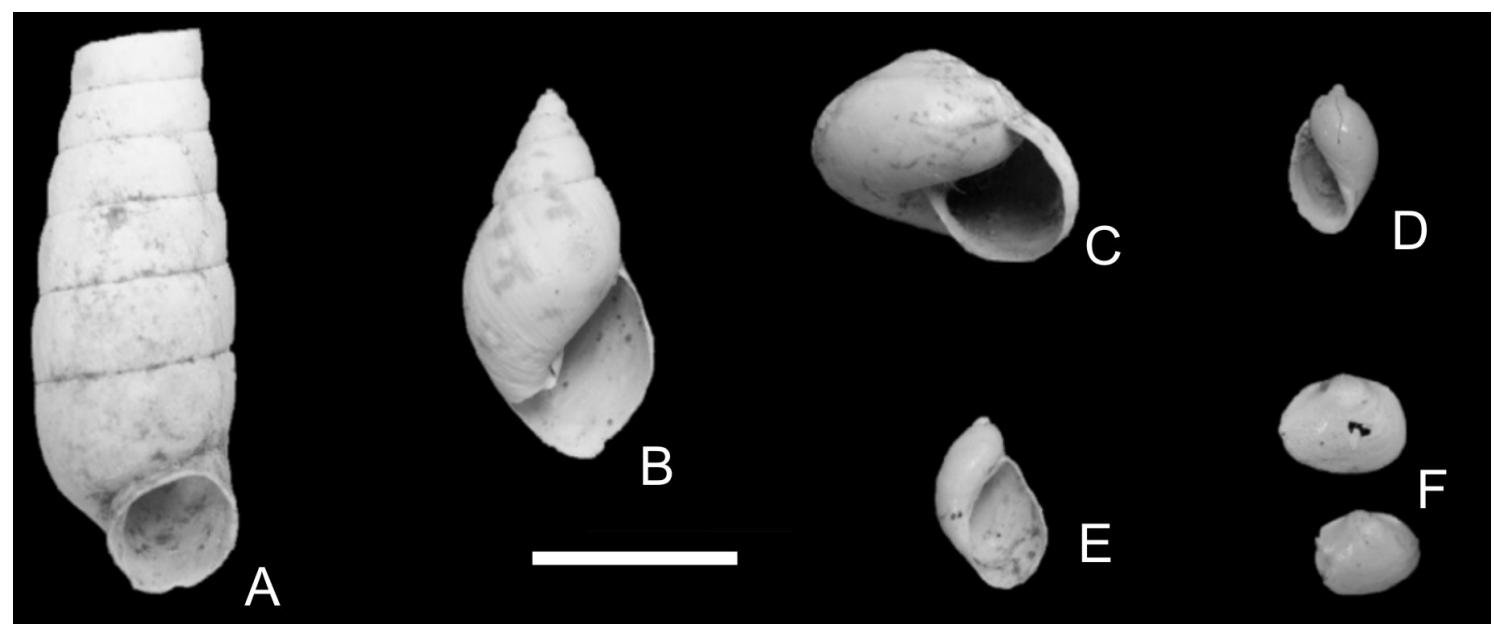

Figure 4. Some invertebrate specimens of the Rancholabrean Viko vijin Local Fauna of Oaxaca, southern Mexico. A, cf. Anisospira; B, cf. Orthalicus; C, Polygyra; D, Physa; E, Succineidae indet.; F, Pisidium. Scale bar $=1 \mathrm{~cm}$. 
Oax 6 with 57 specimens, from locality Oax-6 La Cañada del Misterio; UMLP-Lote 1-Oax 5 with 13 specimens, from locality Oax-5 Llano de Hueso; UMLP-Lote 1-Oax 4 with 8 specimens, from locality Oax-4 Río Salado; UMLP-Lote 1-Oax 7 with 11 specimens, from locality Oax-7 Río Tejupam.

Remarks. The shells of these specimens are medium-sized, disc-shaped or globose. The spire is almost flat. The umbilicus is small. The aperture is rounded.

\section{Order BASOMMATOPHORA Keferstein, 1864 Family PHYSIDAE Fitzinger, 1833 Physa Draparnaud, 1801}

Referred material. UMLP-Lote 2-Oax 4 with 5 specimens, from locality Oax-4 Río Salado.

Remarks. These shells are sinistral, small to medium-sized. The shells are conical and their spiral body whorl is expanded.

\section{Family LYMNAEIDAE Rafinesque, 1815}

Referred material. UMLP-Lote 6-Oax 3 with 30 specimens, from locality Oax-3 La Pedrera; UMLP-Lote 3-Oax 2 with 33 specimens, from locality Oax-2 El Pedernal.

Remarks. These shells are small and elongated, higher than wide. The wall of the shell is thin. The spire is pointed. The aperture is elongate and ovate.

\section{Family PLANORBIDAE Rafinesque, 1815}

Referred material. UMLP-Lote 4-Oax 2 with 134 specimens, from locality Oax-2 El Pedernal; UMLP-Lote 5-Oax 2 with 95 specimens, from locality Oax-2 El Pedernal; UMLP-Lote 4Oax 6 with 80 specimens, from locality Oax-6 La Cañada del Misterio.

Remarks. The shells are discoid, almost planispiral. The shell surface has many growth rings. The umbilicus, when present, is large and wide. Some specimens are very small.

\author{
Class BIVALVIA \\ Subclass HETERODONTA Neumayr, 1884 \\ Order VENEROIDAAdams \& Adams, 1856 \\ Family PISIDIIDAE Gray, 1857 \\ Pisidium Pfeiffer, 1821
}

Referred material. UMLP- Lote 7-Oax 3 with 46 specimens, from locality Oax-3 La Pedrera; UMLP-Lote 6-Oax 2 with 79 specimens from locality Oax-2 El Pedernal; UMLP-Lote 5Oax 6 with 34 specimens from locality Oax-6 La Cañada del Misterio; UMLP-Lote 2-Oax 5 with 3 specimens from locality Oax-5 Llano de Hueso.

Remarks. The shells are small and oval, with the anteroventral margin rounded. The left valve has two cardinal teeth and the right valve has only one cardinal tooth.

Class REPTILIA

Order SQUAMATA Oppel, 1811

Infraorder SCINCOMORPHA Camp, 1923

Referred material. UMPE-069, maxillary with teeth from locality Oax-6 Cañada del Misterio.
Remarks. The specimen is small (length: $2 \mathrm{~mm}$ ); their teeth are short and cylindrical, with simple conical to subrounded crown. These tooth morphology is common among the Scincomorpha. In addition to UMPE-069, there are some other lizard specimens that are now under study to establish their taxonomic identity. This is the first record of lizards for the Mixteca Alta and the first of Pleistocene squamates in Oaxaca.

\author{
Class MAMMALIA \\ Order XENARTHRA Cope, 1889 \\ Suborder CINGULATA Illiger, 1811 \\ Family GLYPTODONTIDAE Gray, 1869 \\ Glyptotherium Osborn, 1903
}

Referred material. UMPE-0021, incomplete caudal tube from locality Oax-4 Río Salado.

Remarks. The caudal tube is articulated, it consists of six caudal rings and each ring is composed of three rows of pentagonal and hexagonal osteoderms. The morphology of UMPE-0021 is typical of Glyptotherium, with two or three osteodem rows per ring, but the dorsal osteoderms of the distal rows are flat, the conical osteoderms are limited to the ventral side of each row.

This is the first record of Glyptotherium in the Rancholabrean of the Mixteca Alta Oaxaqueña (Pérez-Crespo et al., 2008).

\section{Order RODENTIA \\ Family MURIDAE Illiger, 1811 \\ Subfamily SIGMODONTINAE Wagner, 1843}

Referred material. UMPE-0070, m1; UMPE-0071, m2, both specimens from locality Oax-6 Cañada del Misterio.

Remarks. The molars are brachydont, of small size and the typical zigzag occlusal pattern of the group. Besides these molars there are some additional rodent specimens that are now under study to establish their taxonomic identity.

The Rancholabrean record of Rodentia indet. and the sigmodontine rodents in the study area are the first in the Mixteca Alta of Oaxaca; previous Pleistocene records were from central and northeastern Oaxaca (Pérez-Crespo et al., 2008).

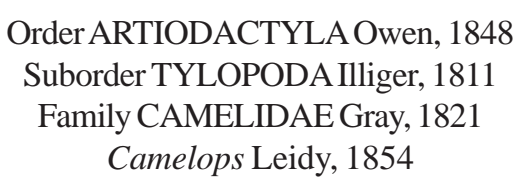

Referred material. UMPE-0026, lower molar from locality Oax2 El Pedernal; UMPE-0072, upper molar from locality Oax-4 Río Salado.

Remarks. Both molars are large, hypsodont and have the flat ectoloph typical of Camelops. This record of Camelops is the first in the late Pleistocene of the Mixteca Alta oaxaqueña (Pérez-Crespo et al., 2008), and links the record of the Tequixquiac fauna, in central Mexico, and Yeroconte L. F., in Honduras (Hibbard, 1955; Webb \& Perrigo, 1984). 


\section{Hemiauchenia Gervais \& Ameghino, 1880}

Referred material. UMPE-0016, tibia from locality Oax-4 Río Salado.

Remarks. The specimen is long and slender, as the limb bones in this Lamini genus. Previously Hemiauchenia was reported in the Late Pleistocene El Cedazo fauna and also in Hidalgo State, central Mexico, as well as in the Loltun Cave (in the Yucatan Peninsula), which is about at the same latitude as is the Trans-Mexican Volcanic Belt (Mooser \& Dalquest, 1975; Arroyo \& Álvarez, 2003; Cuevas-Ruíz, 2005). This new record in northwestern Oaxaca extends its North American geographic distribution from central and eastern Mexico to southern Mexico during the Rancholabrean.

\section{Suborder RUMINANTIA Scopoli, 1777 \\ Family CERVIDAE Gray, 1821 \\ Odocoileus Rafinesque, 1832}

Referred material. UMPE-0073, almost complete antler from locality Oax-6 Cañada del Misterio.

Remarks. The antler is bifurcated and with small longitudinal protuberances on a pedicel's half. This is the second Odocoileus Pleistocene record from Oaxaca and the first for the Mixteca Alta oaxaqueña (Pérez-Crespo et al., 2008).

Family BOVIDAE Gray, 1821

Bison Hamilton-Smith, 1827

Referred material. UMPE-0013, P4, UMPE-0018, horncore fragment, both from Oax-2 El Pedernal; UMPE-0074 almost complete skull from locality Oax-3 La Pedrera; UMPE-0012, lower molar fragment from locality Oax-4 Río Salado.

Remarks. The molars are hypsodont and with the typical bovid occlusal pattern. The horncores are medium-sized and stout. The skull has procumbent orbits, it lacks the nasals and its occipitals are nearly flat.

The presence of Bison in the localities, suggests a Rancholabrean North American Land Mammal age for the Viko vijin L. F. (Bell et. al., 2004).

\section{Order PERISSODACTYLA Owen, 1848 Family EQUIDAE Gray, 1821 Equus sp.}

Referred material. UMPE-0008, maxillary fragment with DP4M3 from locality Oax-7 Río Tejupam; UMPE-0009 to UMPE0011, molars from locality Oax-4 Río Salado; UMPE-0019, two lower molars from locality Oax-5 Llano de Hueso; UMPE-023, phalanx I-III from locality Oax-4 Río Salado; UMPE-0077, skull from locality Oax-5 Llano de Hueso.

Remarks. The skull is slightly depressed, it has full dentition, their molars are hypsodont to very hypsodont, have plicated fossetes and strong styles.

As in other Late Pleistocene faunas from Mexico, such as Texquixquiac and El Cedazo, in the study area there are two different sizes of Equus based on teeth. One consists of large teeth which are $\sim 32 \%$ larger that the other taxon based on medium-sized-teeth.
Recent quantitative studies on Pleistocene equids from Mexico indicate that these size differences reflect different species (Melgarejo-Damian \& Montellano-Ballesteros, 2008). In addition of differences in size, the Mixteca Alta specimens show several differences in morphological character states that suggest the presence of two species. The material is now under detailed study to establish their species identity.

\section{Order PROBOSCIDEA Illiger, 1811 \\ Family GOMPHOTHERIIDAE Hay, 1922 \\ Cuvieronius Osborn, 1923}

Referred material. UMPE-0001, complete pelvis from locality Oax-2 El Pedernal.

Remarks. The specimen is large and stout, the rostral part of the ilium crest is almost the same size as the caudal portion. The acetabulum is stout.

The genus has been reported south of the study area, near the city of Tlaxiaco (Ochoterena \& Silva-Bárcenas, 1970).

$$
\begin{gathered}
\text { Family ELEPHANTIDAE Gray, } 1821 \\
\text { Mammuthus Brooks, } 1828
\end{gathered}
$$

Referred material. UMPE-0025, UMPE-0027 and UMPE-0028, three lumbar vertebrae from locality Oax-7 Río Tejupam; UMPE0029, lower molar from locality Oax-4 Río Salado; UMPE-0076, almost complete tusk from locality Oax-2 El Pedernal.

Remarks. The vertebrae have a wide vertebral foramen and short spinous process. The lower molar has the typical loxodont occlusal pattern of the genus. The tusk has a circular cross-section and is strongly curved.

Together with the Equus remains, those of Mammuthus are the most abundant in the study area.

\section{CONSIDERATIONS ABOUT THE FAUNAL ASSEMBLAGE}

The mammalian taxa identified from the Viko vijin L. F., Oaxaca, are also present at other several well-known Rancholabrean faunas of central and northern Mexico (Table 1). The faunal association from the Mixteca Alta shares nine taxa with the more northern faunas of Terapa (Sonora), Chapala (Jalisco), El Cedazo (Aguascalientes), and Tequixquiac (Mexico) (Table 1).

The Hormiguero L. F. in El Salvador and the Yeroconte L. F. in Honduras, share four taxa with the the Viko vijin L. F. (Table 1). The Late Pleistocene faunas of Nicaragua and Costa Rica share three taxa with the Viko vijin L. F. (Table 1). The faunas of Panama share three taxa and instead of Glyptotherium, Glyptodon is recorded (Cisneros, 2005, Pearson, 2005). Laurito \& Aguilar (2007) reported Mammuthus columbi in three Pleistocene localities from El Salvador, but not in the Hormiguero L. F.

The record of several mammalian taxa in northern, central and southern Mexico, as well as in Central America, suggest that they had a wide geographic distribution during the Late Pleistocene. 
The invertebrate specimens collected from the Mixteca Alta oaxaqueña are the first records of continental Pleistocene mollusks from Oaxaca. Five gastropod taxa are terrestrial, three are freshwater taxa and the bivalve genus also indicates freshwater. The mollusk families of the Viko vijin L. F. are of Neartic affinities because their members have been recovered from several Late Pleistocene and early Holocene localities in northern and central Mexico, as well as diverse Pleistocene localities from Texas, Oklahoma, Kansas and South Dakota (Table 2). The Viko vijin L. F. shares five mollusk families with the Late Pleistocene Rancho La Amapola, San Luis Potosí, central Mexico. It also shares three families with the Lecho Seco del Lago de Tlahuac in the Valley of Mexico and Valsequillo in the Valley of Puebla (Table 2).

The records of these mollusk families in the Late Pleistocene of the Mixteca Alta oaxaqueña are at present their southernmost geographic limit in North America. The families Bulimulidae, Polygyridae and Urocoptidae are recorded for the first time in the Late Pleistocene of Mexico and their presence at the Viko vijin L. F. allows to extend their geographic range from southern USA localities to southern Mexico.

\section{HABITAT CONSIDERATIONS}

Paleoecological studies have shown that dietary preferences of fossil mammals provide insight about their habitat, given that they are intimately related to the vegetation available in a geographic area (e.g. Dompierre \& Churcher, 1996; Merceron et al., 2007; Rivals et al., 2008; Pushkina et al., 2010).

Therefore, in order to have a first approximation about the habitat of the study area during the Late Pleistocene, the probable dietary preferences of the taxa identified during this study were determined using literature and the results are shown in Table 3. Forty four percent of the mammalian genera identified in the Viko vijin L. F., were mainly grazers, while the rest were mixed feeders or browsers (MacFadden \& Cerling, 1996; Koch et al., 1998; Feranec, 2004; Prado et al., 2005; Rivals et al., 2007; DeSantis et al., 2009). This suggests

Table 1. Shared taxa between the Rancholabrean Viko vijin Local Fauna from Oaxaca and the better-studied Late Pleistocene mammalian faunas from México and Central America. Abbreviations: Ter, Terapa, Sonora State; Cha, Chapala, Jalisco State; SJos, San Josecito Cave, Nuevo León State; Ced, El Cedazo, Aguascalientes State; Tex,Tequixquiac, Estado de México; SCruz, Santa Cruz Nuevo, Puebla State; Lol, Lotún Cave, Yucatan State; Vv, Viko vijin, Oaxaca; Hor, Hormiguero, El Salvador; Yer, Yeroconte, Honduras; Nic, Nicaraguan faunas; CoR, Costa Rican faunas; Pan, Panamian faunas. (Data from Hibbard, 1955; Mooser \& Dalquest, 1975; Miller \& Carranza-Castañeda, 1984; Webb \& Perrigo, 1984; Montellano-Ballesteros, 1992; Lucas et al., 1997; Cisneros, 2005; Pearson, 2005; Meade et al., 2006; Laurito \& Aguilar, 2007; Lucas et al., 2008).

\begin{tabular}{|c|c|c|c|c|c|c|c|c|c|c|c|c|c|}
\hline Taxa & Ter & Cha & SJos & Ced & Tex & SCruz & Lol & Vv & Hor & Yer & Nic & CoR & Pan \\
\hline \multicolumn{14}{|l|}{ Xenarthra } \\
\hline Mylodontidae & - & - & & - & - & & & & & & & & \\
\hline Glyptodontidae & & & & & & & & & & & & - & - \\
\hline Glyptotherium & - & - & & - & $\bullet$ & - & & $\bullet$ & - & $\bullet$ & & & \\
\hline Pampatheriidae & - & $\bullet$ & & $\bullet$ & $\bullet$ & $\bullet$ & & & & & & & \\
\hline Lagomorpha & - & $\bullet$ & - & 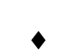 & & $\bullet$ & - & & & & & & \\
\hline Rodentia & & & & & & & & & & & & & \\
\hline Geomyidae & - & & - & - & - & & - & & & & & & \\
\hline Hydrochaeridae & - & - & & 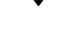 & & & & & & & - & & \\
\hline Muridae & - & - & - & 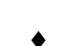 & - & - & - & & & & & & \\
\hline Carnivora & & & & & & & & . & & & & & \\
\hline Canidae & - & $\bullet$ & $\bullet$ & $\bullet$ & $\bullet$ & & - & 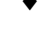 & & & & - & \\
\hline Felidae & - & - & - & 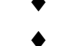 & - & & - & & - & - & & 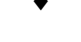 & \\
\hline Procyonidae & - & & $\bullet$ & - & & - & - & & & & $\bullet$ & & \\
\hline \multicolumn{14}{|l|}{ Perissodactyla } \\
\hline \multicolumn{14}{|l|}{ Equidae } \\
\hline $\begin{array}{l}\text { Equus sp. A medium-sized } \\
\text { Equus sp. B large-sized }\end{array}$ & - & $\dot{\square}$ & $\bullet$ & $\dot{\square}$ & $\dot{4}$ & - & - & $\dot{\square}$ & $\bullet$ & $\bullet$ & . & $\bullet$ & $\bullet$ \\
\hline $\begin{array}{l}\text { Equus sp. B large-sized } \\
\text { Tapiridae }\end{array}$ & $\bullet$ & - & - & & & & & & & & & $\bullet$ & \\
\hline \multicolumn{14}{|l|}{ Artiodactyla } \\
\hline Tay assuidae & - & $\bullet$ & & $\bullet$ & - & & $\bullet$ & & & & & & \\
\hline Camelidae & & & & & & & & & & & & & \\
\hline Camelops & - & - & & - & - & & & - & & & & & \\
\hline Hemiauchenia & - & & $\bullet$ & $\bullet$ & $\bullet$ & & - & $\bullet$ & & $\bullet$ & & & \\
\hline \multicolumn{14}{|l|}{ Cervidae } \\
\hline Odocoileus & - & - & & - & & 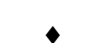 & - & - & & & & & \\
\hline Antilocapridae & - & - & & - & - & 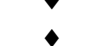 & & & & - & & & - \\
\hline Bovidae & & & & & & - & & & & & & & \\
\hline Bison & - & - & & - & - & & - & - & - & & - & & \\
\hline \multicolumn{14}{|l|}{ Proboscidea } \\
\hline Gomphoteriidae & & & & & & & & & & & & & \\
\hline Cuvieronius & $\bullet$ & $\bullet$ & & & $\bullet$ & & - & • & $\bullet$ & & $\bullet$ & $\bullet$ & $\bullet$ \\
\hline $\begin{array}{l}\text { Elephantidae } \\
\text { Mammuthus }\end{array}$ & 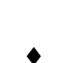 & 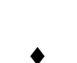 & & . & - & - & 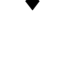 & - & 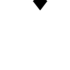 & & - & 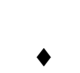 & 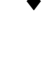 \\
\hline
\end{tabular}


that in addition to grasses and herbs there was a significant component of trees and bushes available to these herbivores.

Likewise, the geographic distribution of mollusks among the fossil localities also suggests an environment with trees and bushes and some semi-permanent water ponds and water streams (Table 4). The freshwater taxa were collected in the surroundings of the town of Concepción Buenavista (northeastern part of the area) and the tree-dwellers were collected in the ravines of Santiago Acutla (in the central part of the study area) (Figure 1).

As was stated in the stratigraphic descriptions, the fossiliferous Pleistocene sediments bear caliche or calcrete nodules, which are absent from the upper and lower beds; remarkably, many of the mammalian specimens have caliche nodules adhered to them. It is known that caliche nodules suggests arid to semiarid conditions where evaporative loss exceeds the supply of water to the surface by rainfall or flooding (Esteban \& Klappa, 1983; Reading, 1996). Therefore, the caliche nodules in association with the mammal fossils

Table 2. Shared mollusk taxa between the Late Pleistocene Viko vijin Local Fauna of Oaxaca and the Late Pleistocene Mexican localities with records of invertebrates; some USA faunas are also shown. (Data from Taylor, 1954; Schultz \& Cheatum, 1970; Jass et al., 2002; Arroyo-Cabrales et al., 2008). Abbreviations: Vv, Viko vijin L. F., Oaxaca; RA, Rancho La Ampola, San Luis Potosi; VA, Villa Acuña, Coahuila (Pleistocene?); RC, Randal County, Texas; Bf, Berends fauna, High Plains, Kansas and Oklahoma; BH, Black Hills, South Dakota.

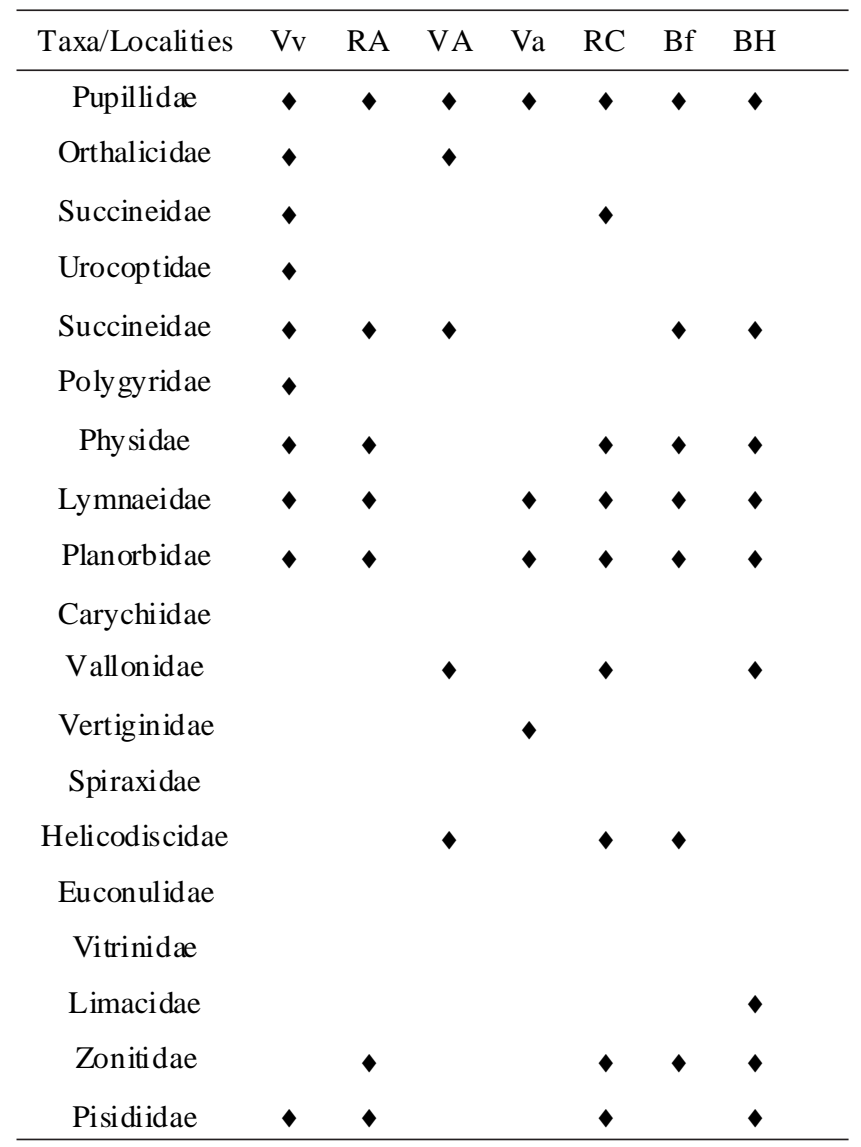

could indicate a dry environment during the burial (or may be the fossilization) of some of the mammalian remains in the study area. This is also supported by the interpretation that the faunal assemblage is an attritional one and likely spans some thousands of years.

This association of freshwater mollusks, mammal bones and caliche nodules, suggest that periods of dry conditions, alternating with others that were more humid, occurred during the deposition of the Late Pleistocene fossiliferous sediments.

The dietary preferences of mammals, the habitat preferences of mollusks and depositional environment of localities, together suggest that the probable habitat of the Rancholabrean Viko vijin L. F. was some type of woodland (Reed, 1998) with grass, a significant component of trees and bush coverage and some semi-permanent ponds and flowing waters (at least during some periods of time) within a cooltemperate environment given the altitude (1800-2400 m) of the study area.

Future dating of fossil localities will establish the precise age of deposition and stable isotope analyses will elucidate precisely the climate and habitat, as well as the dietary preferences of the mammals from the Mixteca Alta oaxaqueña during the Late Pleistocene.

Table 3. Feeding preferences of the mammalian taxa from the Rancholabrean Viko vijin Local Fauna, northwestern Oaxaca, southern Mexico. See text for bibliographic references of feeding preferences of the genera.

\begin{tabular}{|c|c|}
\hline Taxa & Feeding preferences \\
\hline \multicolumn{2}{|l|}{ Mammalia } \\
\hline \multicolumn{2}{|l|}{ Glyptodontidae } \\
\hline Glyptotherium & Grazer/aquatic grazer \\
\hline \multicolumn{2}{|l|}{ Rodentia } \\
\hline \multicolumn{2}{|l|}{ indet. } \\
\hline \multicolumn{2}{|l|}{ Sigmodontinae } \\
\hline \multicolumn{2}{|l|}{ Camelidae } \\
\hline Hemiauchenia & Browser-like mixed feeder \\
\hline Camelops & Mixed feeder \\
\hline \multicolumn{2}{|l|}{ Cervidae } \\
\hline Odocoileus & Browser \\
\hline \multicolumn{2}{|l|}{ Bovidae } \\
\hline Bison & Mixed feeder/grazer \\
\hline \multicolumn{2}{|l|}{ Equidae } \\
\hline Equus sp. A medium-sized & This genus traditionally has \\
\hline Equus sp. B large-sized & been considered grazer \\
\hline \multicolumn{2}{|l|}{ Gomphotheriidae } \\
\hline Cuvieronius & Mixed feeder \\
\hline \multicolumn{2}{|l|}{ Elephantidae } \\
\hline Mammuthus & Grazer \\
\hline
\end{tabular}


Table 4. Mollusk taxa identified in the Rancholabrean Viko vijin Local Fauna, northwestern Oaxaca, and their habitat preferences.

\begin{tabular}{|c|c|}
\hline Taxa & Habitat \\
\hline Pupillidae & $\begin{array}{l}\text { Members of this family usually live in hidden places, like humus, moss or between grooves of tree } \\
\text { bark. They are important plant and organic matter consumers (Naranjo-García, 2003). }\end{array}$ \\
\hline cf. Orthalicus & The Orthalicus species are tree-dwellers (Naranjo-García, 2003). \\
\hline cf. Anisospira & $\begin{array}{l}\text { This genus inhabits calcareous soils, floodplains or lateriric soils. The hills where they live are } \\
\text { relatively dry and hot (Thompson, 1968). }\end{array}$ \\
\hline Succineidae & $\begin{array}{l}\text { Some me mbers of this family inhabit under rocks, leaf litter in mixed forests or broadleaf shrubs and } \\
\text { trees (Forsyth, 2005); they live under humid conditions (Arroyo-Cabrales et al., 2008). }\end{array}$ \\
\hline Polygyra & $\begin{array}{l}\text { The genus has a wide distribution in North America, from peninsular Florida to South Carolina and } \\
\text { west of Mexico. Inhabits in maritime to high montane habitats and from arid regions to humid } \\
\text { woodlands (Auffenberg \& Stange, 1989). }\end{array}$ \\
\hline Physa & They are common freshwater gastropods, inhabiting lakes, ponds and small rivers (Taylor, 2003). \\
\hline Lymnaeidae & Members of this family are freshwater gastropods that feed algae and detritus (Dillon, 2000). \\
\hline Planorbidae & $\begin{array}{l}\text { The members of this family are in almost every freshwater environment, from lakes to small pond. } \\
\text { Almost all of their members are littoral animals living up to } 4.5 \text { meters depth (Baker, 1945). }\end{array}$ \\
\hline Pisidium & $\begin{array}{l}\text { This genus inhabits the pond's shore, associated with Lucidella lirata and planorbids (Naranjo- } \\
\text { García, 2003). Members of this genus inhabit permanent water bodies (Schultz \& Cheatum, 1970). }\end{array}$ \\
\hline
\end{tabular}

\section{CONCLUSIONS}

At present knowledge of the Mexican Pleistocene is incomplete and biased because the record of the central and northern faunas from Mexico is greater when compared to those from the southern Mexico. Paleontological field work carried out in the Mixteca Alta, Oaxaca, in southern Mexico led to the discovery of several fossiliferous sites where mollusk and vertebrate remains were recovered. The whole area was named Viko vijin Local Fauna.

The fossil remains were recovered from six new localities (Oax-2 to Oax-7), whose sediments are constituted by silty clay, silty sand, fine-grained and medium-grained sand. The sedimentary systems represent bars or natural leeves and floodplain deposits of stream channels.

The preservation of the fossil material and the sedimentological information suggest that the faunal association had very limited fluvial transport and represents an indigenous within habitat assemblage.

The mammals identified include a glyptodont (Glyptotherium), two llama genera (Hemiauchenia and Camelops), a deer (Odocoileus), two proboscidean genera (Cuvieronius and Mammuthus), two Equus species, rodents and Bison, which indicates a Rancholabrean North American Land Mammal Age for the association. In addition, several scincomorph lizard specimens were recovered. The mollusks are represented by one species of freshwater bivalve and eight gastropod taxa including five terrestrial and three of freshwater affinities.

The mammals identified are also present at several localities from central and northern Mexico. The Viko vijin $\mathrm{L}$. F. shares nine taxa with the Rancholabrean local faunas of
Terapa (Sonora), northwestern Mexico, Chapala (Jalisco) El Cedazo (Aguascalientes) and Tequixquiac (Mexico), in central Mexico. Likewise, five of the eight mollusk families identified are also present in Rancho La Amapola, San Luis Potosi, central Mexico.

The presence of the llama Hemiauchenia in Oaxaca represents the southernmost record of this genus during Late Pleistocene times. The presence of the scincomorph lizards in this area is the first for Oaxaca. Similarly, the records of the mollusk families Bulimulidae, Polygyridae and Urocoptidae in the Mixteca Alta oaxaqueña are the first for Mexico and allow extending their geographic range from southern USA to southern Mexico.

The probable habitat of the study area during the Late Pleistocene was a mosaic of woodland with grass, trees and bush, within a cool to temperate environment and with some episodes of dry climate and other episodes of more humid climate.

\section{ACKNOWLEDGMENTS}

The authors thank the municipal authorities of Concepción Buenavista, Teotongo, San Antonio Acutla and Villa Tejupam de la Unión for the permits to prospect their lands and their kind hospitality during the fieldwork. Thanks to the Santamaría family for their friendship and great hospitality during the field season at Concepción Buenavista. Thanks to J. Arroyo-Cabrales for sharing a copy of the database "La mastofauna del Cuaternario tardío de Mexico". The authors acknowledge M. González-Quintero and the biology students C. López-Pacheco, M. Campos-Camacho and J. Rodríguez-Rodríguez for helping during fieldwork and 
the preparation of fossil material. This study was funded by CONACyT- Ciencia Básica (CB-2007-01 and CB-2008-01, projects $n^{\circ} 78793$ and $\left.n^{\circ} 101626\right)$. Thanks to the authorities from UMAR for the space to establish the Laboratory of Paleobiology, and to M. Montellano-Ballesteros and E.V. Oliveira for their valuable suggestions that helped to improve this work.

\section{REFERENCES}

Arroyo-Cabrales J.A. \& Johnson, E. 1995. A reappraisal of fossil vertebrates from San Josecito Cave, Nuevo León, Mexico. In: E. Johnson (ed.) Ancient peoples and landscapes, Texas Museum/Texas Tech University, p. 217-231.

Arroyo-Cabrales J. \& Álvarez, T. 2003. A preliminary report of the Late Quaternary mammal fauna from Loltún Cave, Yucatán, Mexico. In: B.W., Schubert; J.I., Mead \& R.W. Graham (eds.) Ice age cave faunas of North America, Indiana University Press $\&$ Denver Museum of Nature and Science, p. 262-272.

Arroyo-Cabrales J. \& Johnson, E. 2003. Catálogo de los ejemplares tipo procedentes de la Cueva de San Josecito, Nuevo León, Mexico. Revista Mexicana de Ciencias Geológicas, 20(1):79-83.

Arroyo Cabrales, J.; Polaco, O.J. \& Johnson, E. 2002. La mastofauna del Cuaternario tardío de Mexico. In: M. Montellano-Ballesteros \& J. Arroyo-Cabrales (eds.) Avances en los estudios paleomastozoológicos en Mexico, Ciudad de Mexico, INAH, p. 103-123 (Colección Científica, Serie Arqueología 443).

Arroyo-Cabrales, J.; Carreño, A.L.; Lozano-García, S. \& Montellano-Ballesteros M. 2008. La diversidad en el pasado. In: J. Sarukhán (coord.) Capital natural de Mexico, volumen I: conocimiento actual de la biodiversidad, Conabio, p. 227-262.

Aslan, A. \& Behrensmeyer, A. 1996. Taphonomy and time resolution of bone assemblages in a contemporary fluvial system; the East Fork River, Wyoming. Palaios, 11:411-421.

Auffenberg, K. \& Stange, L.A. 1989. The Polygyridae (Gastropoda: Pulmonata) of Florida. 1. Key to the genera and subgenera. Entomology Cicular, 317:1-4.

Baker, F.C. 1945. The molluscan Family Planorbidae. Collation, revision and additions by H.J. Van Cleave. Champaign, University of Illinois Press, 530 p.

Behrensmeyer, A.K. 1982. Time resolution in fluvial vertebrate assemblages. Paleobiology, 8(3):211-227.

Behrensmeyer, A.K. \& Hook, R.W. 1992. Paleoenvironmental contexts and taphonomic modes. In: A.K. Behrensmeyer; J.D. Damuth; W.A. DiMichele; R. Potts; H-D. Sues \& S.L. Wing (eds.) Terrestrial ecosystems through time, evolutionary paleoecology of terrestrial plants and animals, University of Chicago Press, p. 15-136.

Bell, C.J.; Lundelius E.L. Jr.; Barnosky, A.D.; Graham, R.W.; Lindsay, E.H.; Ruez, D.R. Jr.; Semken, H.A. Jr.; Webb, S.D. \& Zakrzewski, R.J. 2004. The Blancan, Irvingtonian, and Rancholabrean Mammal Ages. In: M.O. Woodburne (ed.) Late Cretaceous and Cenozoic mammals of North America, biostratigraphy and geochronology, Columbia University Press, p. 232-314.

Boggs, S. 2001. Principles of sedimentology and stratigraphy. $3^{\mathrm{a}}$ ed. New Jersey, Prentice Hall, 726 p.

Cassiliano, M. 1997. Taphonomy of mammalian fossils across the Blancan-Irvingtonian boundary: Palm Springs Formation, AnzaBorrego desert of southern California. Palaeogeography, Palaeoclimatology, Palaeoecology, 129(1-2):81-108. doi:10.1016/S0031-0182(96)00123-X
Cisneros, J.C. 2005. New Pleistocene vertebrate fauna from El Salvador. Revista Brasileira de Paleontologia, 8(3):239-255.

Cuevas Ruiz, G.E. 2005. Los camelidos pleistócenicos de los estados de Hidalgo, Puebla y Tlaxcala: taxonomía y paleobiología. Instituto de Ciencias Básicas e Ingeniería, Universidad Autónoma del Estado de Hidalgo, Bachelor Biology thesis, 111 p.

DeSantis, L.R.; Feranec, R.S. \& MacFadden, B.J. 2009. Effects of global warming on ancient mammalian communities and their environments. PLoS ONE, 4(6):e5750. doi: 10.1371/ journal.pone.0005750

Dillon, R.T. Jr. 2000. The ecology of freshwater mollusks. $1^{\mathrm{a}}$ ed. Cambridge, Cambridge University Press, 509 p.

Dompierre, H. \& Churcher, C.S. 1996. Premaxillary shape as an indicator of the diet of seven extinct late Cenozoic New World camels. Journal of Vertebrate Paleontology, 16(1):141-148. doi: 10.1080/02724634.1996.10011292

Doutt, J.K. \& Craig, C.B. 1962. A new Pleistocene locality in the State of Oaxaca, Mexico. Journal of Mammalogy, 43(3):414-415.

Eronen, J.T. 2007. Locality coverage, metacommunities and chronofauna: concepts that connect paleobiology to modern population biology. Vertebrata Palasiatica, 45(2):137-144.

Esteban, M. \& Klappa, C.F. 1983 Subaerial exposure environment, In: P.A. Scholle; D.G. Bebout; \& C.H. Moore (eds.) Carbonate depositional environments, AAPG Memoir 33, p. 2-54.

Feranec, R.S. 2004. Geographic variation in the diet of hypsodont herbivores from the Rancholabrean of Florida: Palaeogeography, Palaeoclimatology, Palaeoecology, 207(3-4):359-369. doi:10.1016/j.palaeo.2003.09.031

Ferrusquía-Villafranca, I. 1970. Geología del área TamazulapanTeposcolula-Yanhuitlán, Mixteca Alta, Estado de Oaxaca. In: Sociedad Geológica Mexicana, Libro-guía excursión MexicoOaxaca, p. 97-119.

Ferrusquía-Villafranca, I.; Arroyo-Cabrales, J.; MartínezHernández, E. \& Gama-Castro, J. 2007. Pleistocene mammals of Mexico: a critical review of regional chronofaunas, biogeographic provinciality and climatic change response. In: ANNUAL MEETING SOCIETY OF VERTEBRATE PALEONTOLOGY, 67, 2007. Abstracts of Papers, Austin, SVP, 27(3):74A.

Fiorillo, A.R. 1988. Taphonomy of Hazard Homestead Quarry (Ogallala Group), Hichcock County, Nebraska. Contributions to Geology, University of Wyoming, 26(2):57-97.

Forsyth, R.G. 2005. Terrestrial gastropods of the Peace RiverNorthern Rockies Region of British Columbia. Victoria, Royal British Columbia Museum, $23 \mathrm{p}$.

Gill, J.L; Williams, J.W.; Stephen T. J.; Lininger, K.B. \& Robinson, G.S. 2009. Pleistocene megafaunal collapse, novel plant communities, and enhanced fire regimes in North America. Nature, 326:1100-1103. doi: 10.1126/science.1179504

Gonzáles-Ramos, A.; Sánchez-Rojas, L.E.; Mota-Mora, S.; Arceo y Cabrilla, F.A.; Onofre-Espinoza, L.; Zárate-López, J. \& SotoAraiza, R. 2000. Carta geológico-minera Oaxaca, E14-9, Oaxaca y Puebla, Escala 1:250,000. Pachuca, Servicio Geológico Mexicano, $64 \mathrm{p}$.

Hibbard, C.W. 1955. Pleistocene vertebrates from the Upper Becerra (Becerra Superior) Formation, Valley of Tequixquiac, Mexico, with notes on other Pleistocene forms. Contributions Museum of Paleontology, The University of Michigan, 12(5):47-96.

Jiménez-Hidalgo, E. \& Carranza-Castañeda, O. 2005. Hemphillian camelids and protoceratids from San Miguel de Allende, Guanajuato State, central Mexico. In: ANNUAL MEETING SOCIETY OF VERTEBRATE PALEONTOLOGY, 65, 2005. Abstracts of Papers, Arizona, SVP, 25(3):75A. 
Jiménez-Hidalgo, E. \& Carranza-Castañeda, O. 2009. Paleobiología de los artiodáctilos selenodontes del Plioceno de San Miguel de Allende, Guanajuato, Mexico. In: CONGRESO NACIONAL DE PALEONTOLOGÍA, 11, 2009. CD de resúmenes, Juriquilla, SOMEXPAL.

Jiménez-Hidalgo, E.; Guerrero-Arenas R.; Santiago-Romero, H. \& Ceballos-Gutierrez, K.L. 2007. A preliminary report on a new Pleistocene faunal site from northeastern Oaxaca, southern Mexico. In: ANNUAL MEETING SOCIETY OF VERTEBRATE PALEONTOLOGY, 67, 2007. Abstracts of Papers, Austin, SVP, 27(3):95A.

Jass, C.N.; Mead, J.I.; Morrison, A.D. \& Agenbroad, L.D. 2002. Late Pleistocene mollusks from the southern Black Hills, South Dakota. Western North American Naturalist, 62(2):129-140.

Kidwell, S.M. \& Flessa, K.W. 1996. The quality of the fossil record: populations, species, and communities. Annual Review of Earth and Planetary Sciences, 24:433-464. doi: 10.1146/annurev.earth.24.1.433

Koch, P.L.; Hoppe, K.A. \& Webb, S.D. 1998. The isotopic ecology of Late Pleistocene mammals in North America Part 1. Florida. Chemical Geology, 152(1-2):119-138. doi:10.1016/S00092541(98)00101-6

Koch, P.L. \& Barnosky, A.D. 2006. Late Quaternary extinctions: state of the debate. Annual Review of Ecology, Evolution, and Systematics, 37:215-250. doi: 10.1146/ annurev.ecolsys.34.011802.132415

Kotzian, C.B. \& Simões, M.G. 2006. Taphonomy of Recent freshwater molluscan death assemblages, Touro Passo stream, southern Brazil. Revista Brasileira de Paleontologia, 9(2):243-260.

Laurito Mora, L. \& Aguilar, D.H.C. 2007. El registro de Mammuthus (Proboscidea, Elephantidae) en la República de El Salvador, América Central. Revista Geológica de América Central, 34:73-81.

Lindsay, E.H. 1984. Late Cenozoic mammals from northwestern Mexico. Journal of Vertebrate Paleontology, 4(2):208-215. doi: 10.1080/02724634.1984.10012004

Lucas, S. 2008. Late Cenozoic fossil mammals from the Chapala rift basin, Jalisco, Mexico. New Mexico Museum of Natural History and Science Bulletin, 44:39-49.

Lucas, S.G.; Alvarado, G.E. \& Vega, E. 1997. The Pleistocene mammals of Costa Rica. Journal of Vertebrate Paleontology, 17(2):413-427. doi: 10.1080/02724634.1997.10010985

Lucas, S.; Garcia, R.; Espinoza, E.; Alvarado, G.E.; De Mendoza, L. \& Vega, E. 2008. The Fossil Mammals of Nicaragua. New Mexico Museum of Natural History and Science Bulletin, 44:417-429.

MacFadden, B.J. \& Cerling, T. 1996. Mammalian herbivore communities, ancient feeding ecology and carbon isotopes: a 10 million-year sequence from the Neogene of Florida. Journal of Vertebrate Paleontology, 16(1):103-115. doi: 10.1080/ $02724634.1996 .10011288-115$

Mead J.I.; Baez, A.; Swift, S.L.; Carpenter, M.C.; Hollenshead, M.; Czaplewski, N.J.; Steadman, D.W.; Bright, J. \& ArroyoCabrales, J. 2006. Tropical marsh and savanna of the Late Pleistocene in northeastern Sonora, Mexico. The Southwestern Naturalist, 51(2):226-239. doi: 10.1894/00384909(2006)51[226:TMASOT]2.0.CO;2

Melgarejo-Damian, P.M. \& Montellano-Ballesteros M., 2008. Quantitative differentiation of Mexican Pleistocene. Current Research in Pleistocene, 25:184-186.

Merceron, G.; Blondel, C.; Viriot, L.; Koufos, G.D. \& Bonis, L. 2007. Dental microwear analysis of bovids from the Vallesian (late Miocene) of Axios Valley in Greece: reconstruction of the habitat of Ouranopithecus macedoniencis (Primates, Hominoidea). Geodiversitas, 29(3):421-433.

Miall, A.D. 1982. Analysis of fluvial depositional systems. Tulsa, American Association of Petroleum Geologists, 75 p. (Education Course Note Series 20).

Miller, W.E. \& Carranza-Castañeda, O. 1984. Late Cenozoic mammals from central Mexico. Journal of Vertebrate Paleontolology, 4(2):216-236. doi: 10.1080/02724634.1984.10012005

Montellano-Ballesteros, M. 1992. Una edad del Irvingtoniano al Rancholabreano para la fauna Cedazo del Estado de Aguascalientes. Revista del Instituto de Geología, 9(2):195-203.

Montellano-Ballesteros, M. \& Jiménez-Hidalgo, E. 2006. Mexican fossil mammals, who, where and when? In: F. Vega-Vera; G.N. Torrey; M.A. Perrillat; M. Montellano-Ballesteros; S.R.S. Cevallos-Ferriz \& S. Quiroz-Barroso (eds.) Studies on Mexican Paleontology, Springer, p. 249-273.

Mooser, O. \& Dalquest, W. 1975. Pleistocene mammals from Aguascalientes, central Mexico. Journal of Mammalogy, 56(4):781-820.

Moore, J.R. \& Norman, D.B. 2009. Quantitatively evaluating the source of taphonomic biasing of skeletal element abundances in fossil assemblages. Palaios, 24:591-602. doi: 10.2110/ palo.2008.p08-135r

Morales-Mejía, F.M.; Arroyo-Cabrales, J. \& Polaco, O.J. 2009. New records for the Pleistocene fauna from Loltun Cave, Yucatan, Mexico. Current Research in the Pleistocene, 26:166-168.

Naranjo-García, E. 2003. Moluscos continentales de Mexico: terrestres. Revista de Biología Tropical, 51(3):483-493.

Nichols, G. 1999. Sedimentology and stratigraphy. Malden, Blackwell Science, 355 p.

Ochoterena, H. \& Silva-Bárcenas, A. 1970. Cuvieronius arellanoi sp. n., mastodonte del Pleistoceno del estado de Oaxaca. Paleontología Mexicana, 33(1):1-25.

Ortiz-Pérez, M.A.; Hernández-Santana, J.R. \& Figueroa Mah-Eng, J.M. 2004. Reconocimiento fisiográfico y geomorfológico. In: A.J. García-Mendoza; M.J. Ordoñez \& M. Briones-Salas (eds.) Biodiversidad de Oaxaca, Instituto de Biología, UNAM/Fondo Oaxaqueño para la Conservación de la Naturaleza, p. 43-54.

Pearson, G.A. 2005. Late Pleistocene Megafaunal deposits on the Isthmus of Panama and their paleoenvironmental implications. Caribbean Journal of Science, 41(1):1-13.

Pérez-Crespo, A.; Arroyo-Cabrales, J. \& Santos Moreno, A. 2008. Generalidades de los mamíferos del Pleistoceno Tardío de Oaxaca. Naturaleza y Desarrollo, 6(2):5-11.

Prado, J.L.; Alberdi, M.T.; Azanza, B.; Sánchez, B. \& Frassinetti, D. 2005. The Pleistocene Gomphotheriidae (Proboscidea) from South America. Quaternary International, 126(128):21-30. doi:10.1016/j.quaint.2004.04.012

Prothero, D. 2006. After the dinosaurs: the age of mammals. $1^{\circ} \mathrm{ed}$. Indianapolis, Indiana University Press, $362 \mathrm{p}$.

Pushkina, D.; Bocherens, H.; Chaimanee, Y. \& Jaeger, J.J. 2010. Stable carbon isotope reconstructions of diet and paleoenvironment from the late Middle Pleistocene Snake Cave in Northeastern Thailand. Naturwissenschaften, 97:299-309. doi: 10.1007/s00114-009-0642-6

Quevedo-Robles, P. \& Quevedo de Henell, T. 2001. Two mammoth sites in la Alta Mixteca (Oaxaca), Mexico. In: THE WORLD OF ELEPHANTS-INTERNATIONAL CONGRESS, 1, 2001. Libro de Resúmenes, Rome, CNR, p. 377.

Raup, D.M. \& Stanley, S.M. 1978. Principles of Paleontology. $2^{\circ}$ ed. New York, Freeman and Company, 481 p. 
Reading, G.H. 1996. Sedimentary environments: processes, facies and stratigraphy. $3^{\circ}$ ed. Malden, Blackwell Science, 688 p.

Reed, K.E. 1998. Using large mammal communities to examine ecological and taxonomic structure and predict vegetation in extant and extinct assemblages. Paleobiology, 24(3):384-408.

Reineck, H-E. \& Singh, I.B. 1975. Depositional sedimentary environments with reference to terrigenous clastics. ${ }^{\mathrm{a}}$ ed. New York, Springer-Verlag, $438 \mathrm{p}$.

Rivals, F.; Mihlbachler, M. \& Solounias N. 2007. Effect of ontogenetic-age distribution in fossil and modern samples in the interpretation of ungulate paleodiets using the mesowear method. Journal of Vertebrate Paleontology, 23(3):763-767. doi:10.1671/0272-4634(2007)27[763:EOODIF]2.0.CO;2

Rivals, F.; Schulz, E. \& Kaise, T.M. 2008. Climate-related dietary diversity of the ungulate faunas from the middle Pleistocene succession (OIS 14-12) at the Caune de l'Arago (France). Paleobiology, 34(1):117-127. doi: 10.1666/07023.1

Santamaría-Díaz, A.; Alaníz-Álvares, S.A. \& Nieto-Samaniego, A.F. 2008. Deformaciones cenozoicas en la cobertura de la falla Caltepec en la region de Tamazulapam, sur de Mexico. Revista Mexicana de Ciencias Geológicas, 25(3):494-516.

Schultz, G.E. \& Cheatum, E.P. 1970. Bison occidentalis and associated invertebrates from the late Wisconsin of Randall County, Texas. Journal of Paleontology, 44(5):836-850.

Silva-Bárcenas, A. 1993. Las especies de Mammuthus y la distribución de sus restos en Mexico. In: CONGRESO NACIONAL DE PALEONTOLOGÍA, 4, 1993. México, Libro de Resúmenes, SOMEXPAL, p. 104-105.
Taylor, D.W. 1954. A new Pleistocene fauna and new species of fossil snails from the High Plains. Ann Arbor, University of Michigan, Museum of Zoology, 16 p. (Occasional Papers 557).

Taylor, D.W. 2003. Introduction to the Physidae (Gastropoda: Hygrophila): biogeography, classification, morphology. Revista de Biología Tropical, 51(1):1-287.

Thompson, F.C. 1968. Some Mexican land snails of the Family Urocoptidae. Bulletin of the Florida State Museum, 12(3):125-183.

Tomašových, A. \& Kidwell, S.M. 2010. The effects of temporal resolution on species turnover and on testing metacommunity models. American Naturalist, 175:587-606. doi: 10.1086/651661

Tovar, R.E.; Montellano-Ballesteros M. \& Corona, E. 2007. Fauna pleistocénica de Santa Cruz Nuevo, Puebla, Mexico, In: EUROPEAN MEETING ON THE PALAEONTOLOGY AND STRATIGRAPHY OF LATIN AMERICA, 4, 2007. Cuadernos del Museo Geominero, Madrid, Instituto Geológico y Minero de España, v. 8, p. 393-397.

Van Devender, T.R.; Rea, A.M. \& Smith, M.L. 1985. The Sangamon interglacial vertebrate fauna from Rancho La Brisca, Sonora, Mexico. Transactions San Diego Society of Natural History, 21(1):23-55.

Walker, J.D. \& Geissman, J.W. 2009. Geologic Time Scale. Geological Society of America, doi: 10.1130/2009. CTS004R2C.

Webb, S.D. \& Perrigo, S.C. 1984. Late Cenozoic vertebrates from Honduras and El Salvador. Journal of Vertebrate Paleontology, 4(2):237-254. doi: 10.1080/02724634.1984.10012006

Received in April, 2010; accepted in December, 2010. 